Cornell University Law School Scholarship@Cornell Law: A Digital Repository

Spring 2014

\title{
Learning by Doing: Adding a Clinical Component to a Traditional Family Law Course
}

Cynthia Grant Bowman

Cornell Law School, cgb28@cornell.edu

Follow this and additional works at: https://scholarship.law.cornell.edu/facpub

Part of the Family Law Commons, and the Legal Education Commons

\section{Recommended Citation}

Cynthia Grant Bowman, " Learning by Doing: Adding a Clinical Component to a Traditional Family Law Course," 29 Wisconsin Journal of Law, Gender \& Society 129 (2014)

This Article is brought to you for free and open access by the Faculty Scholarship at Scholarship@Cornell Law: A Digital Repository. It has been accepted for inclusion in Cornell Law Faculty Publications by an authorized administrator of Scholarship@Cornell Law: A Digital Repository. For more information, please contact jmp8@cornell.edu. 


\title{
WISCONSIN JOURNAL OF LAW, GENDER \& SOCIETY
}

VOLUME XXIX, NUMBER 1

SPRING 2014

\section{ESSAY}

\section{LEARNING BY DOING: ADDING A CLINICAL COMPONENT TO A TRADITIONAL FAMILY LAW COURSE}

\author{
Cynthia Grant Bowman*
}

\begin{abstract}
I.A Proposal to AdD a Clinical COMPONENT to A FAMILy LAW
COURSE 131

II.EXPLORING UNMET LEGAL NEEDS IN THE LOCAL COMMUNITY ..................133

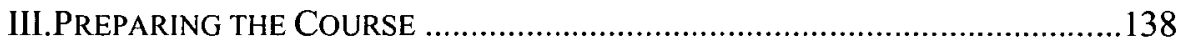

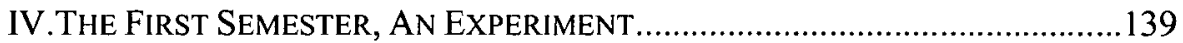

V.IMPROVING AND INSTITUTIONALIZING THE NEW COURSE...........................141

VI.STUDENT RESPONSE TO THE NEW COURSE AND MY RESPONSE TO IT ........143

VII.THE FUTURE OF THE CLINICAL COMPONENT OF FAMILY LAW ..................147

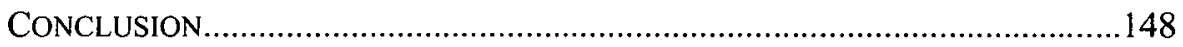

This paper describes a clinical component recently added to the course in Family Law at Cornell Law School. Students who are either co-registered for or have previously taken Family Law receive an extra two credits for clinical work under the instructor's supervision. Each student undertakes to represent at least one client, who is referred from Neighborhood Legal Services, from the initial client interview through drafting, filing and service of the many documents required to obtain a final judgment for dissolution of marriage in New York State. In order to complete this work in one semester, the students do relatively simple divorces that will result in a default judgment. In addition to obtaining a divorce judgment on behalf of a client, students are required to staff a desk in the local family court for three hours a week in rotation, to assist persons filling out petitions for support, modification of support, or for violation of a support order.

* Dorothea S. Clarke, Professor of Feminist Jurisprudence, Cornell Law School. 
Since 2007, I have taught at Cornell Law School, a part of Cornell University, which was founded in 1865 as a land grant college under the Morrill Land Grant Act, with an attached requirement of service to the community that surrounds its campus. ${ }^{1}$ This service orientation continues to the present. $^{2}$ In particular, faculty throughout the university are encouraged to develop courses with a service-learning component and given incentives for doing so. So far, as I can tell, the university has not seen the law school as involved in this aspect of the university, even though a Legal Aid Clinic was established there in the mid-1960s, which offered for-credit courses from 1971 to $1972{ }^{3}$ When a call for proposals to develop a service-learning course went out in early 2011, I was eager to submit an application. This article describes both that proposal and the hybrid Family Law/Family Law Clinic course that I established at Cornell Law School in 2012.

I have long been a fan of Paolo Freire's theory of education, ${ }^{4}$ and I began my law-teaching career as a clinician. Almost two decades ago, I was gradually drawn into doctrinal teaching and ended up as a specialist in feminist legal topics and family law. Traditional pedagogy in U.S. law schools is an archetypical example of Freire's banking concept of education, under which the teacher controls the content of what is learned and transmits it from a position of superiority into the brains of his or her students. ${ }^{5}$ Freire's pedagogy, by contrast, would turn teacher and student into co-investigators of the world, seeking knowledge in order to solve problems. ${ }^{6}$ Clinical teachers and theorists have long imbibed Freire's writings and applied them to their practice and scholarship. ${ }^{7}$ Students in legal clinics learn the law because they need to know it in order to solve real-world problems of real-life clients. ${ }^{8}$ Although I very much enjoy introducing my students in Family Law to the many interesting theoretical issues about why and when the state should intervene in individuals' private lives and what rules should apply when it does, I have no illusion that any student would emerge from the course ready to help someone with a legal

1. See Association of Public and Land-Grant Universities, The Land-Grant TRADITION 1-4 (2012); MORRIS BISHOP, A History OF CORNELl 57, 69 (1962).

2. See, e.g., Cornell Public Service Center, CORNell UNIVERSITY, http://www.psc.cornell.edu/template-01-657.php (last visited Dec. 28, 2012).

3. Email from Barry Strom, former Cornell Legal Aid attorney and a Cornell Law graduate in the early years of the clinical program to Cynthia Grant Bowman (Dec. 28, 2012) (on file with author).

4. Paulo Freire, Pedagogy of The Oppressed (30th Anniversary ed. 2000).

5. See id. at 72 .

6. See id. at 81 .

7. See, e.g., Jane H. Aiken, The Clinical Mission of Justice Readiness, 32 B. C. J. L. \& Soc. JusT. 231, 241 (2012); See also Julie Macfarlane, Teacher Power in the Law School Classroom, 19 Dalhousie L. J. 71, 86-87, 97-103 (1996).

8. When I was a clinical teacher, an exchange with a student perfectly illustrated this point for me. I asked the student whether he had obtained service of process yet, and he looked blank. As I began to explain serving the complaint upon the defendant, a look of sudden understanding transformed the student's face. "That," he said, "is what they were talking about in those rules in civil procedure class!” 
problem involving domestic relations. In one sense, therefore-that of Freire's theory of pedagogy - the student would not really have "learned" family law. So, I have long thought about adding a clinical component to my regular family law course.

In the sections that follow, I describe the process by which this dream became reality. In Part I, I describe and include the text of the proposal I developed, even though it differed in many ways from the course that resulted. In Part II, I relate the semester I spent exploring what were unmet legal needs in the area of domestic relations in Tompkins County, New York, determining which of those needs could be addressed by law students, while also advancing their own professional skills. In Part III, I discuss how I structured the course and prepared the materials with which to teach it. Part IV describes the first semester during which I taught the new Family Law Clinic, while I was still in the process of inventing it. Part V is the story of the next semester, when I was concerned both with improving and institutionalizing the hybrid course as a part of the Cornell Law curriculum. In Part VI, I record the response of the students who participated in the Family Law Clinic sections during those two semesters and my reactions to their suggestions. Their feedback was an invaluable contribution to the further development of the course. Part VII consists of my musings about what will become of the course in the future, as I incorporate the students' ideas into its evolution.

\section{A PRoposal to AdD a CliniCAl COMPONENT to a FAMILy LaW COURSE}

My first step toward adding a clinical component to my family law course was to apply for a grant. Indeed, the call for proposals to include servicelearning was what motivated me to start the process I had long contemplated. Drafting a proposal, I have found, is a good way to figure out exactly what you want to do and how you might possibly go about it. When I begin to write a book proposal, for example, I often ask to see other people's proposals to use as models. Thinking it may be helpful to other law professors interested in adding some form of learning-by-doing component to their family law courses, I am therefore including a substantial excerpt from the proposal I submitted concerning creation of a service-learning course:

Tompkins County has vast unmet legal needs in the areas of both family law and domestic violence. Many litigants are required to go to court without legal representation, an unenviable position. I propose to develop a course at Cornell Law School that will help to address this need while providing a much-needed expansion of the curriculum. It will also provide a model for further expansion of such course offerings. I will do this by adding an additional credit to a substantive 3-credit law school academic course, which will be a service-learning component. No such course currently exists at the law school....

Students will be able to elect to take the course with or without the service-learning component. (Depending on supervisory capacity, 
there might need to be a cap on the number who could add the service-learning component. ${ }^{9}$ ) Students who elect to take the course with the service-learning component would participate in the regular class and also each undertake work on behalf of an individual client in the Ithaca area.

Family law and domestic violence courses are particularly appropriate for the addition of a service-learning component. Law students who obtain an intern license under N.Y. COMP. CODES R. \& REGS. tit. 22, Section 805.5 (2013) are allowed to perform in-court work and thus could, for example, litigate an uncontested divorcefrom the initial client interview through judgment- during the course of a semester. Students who did so would learn important interviewing, drafting, and in-court advocacy skills as well as the substantive law. They would do so, of course, under careful supervision either by me or a member of the law school's clinical faculty.... The model I propose could work well for courses in other areas of law. The research and experience I will bring to this project will thus be useful to the development of the Cornell law school curriculum on an ongoing basis. This will be a timely enhancement of the school's capability because the American Bar Association has recently added a requirement that each law student must earn at least one credit in a skills-oriented course.

This is a model I know has been employed at a few other law schools ... ${ }^{10}$ In Ithaca, I will meet with service providers in the selected subject area-for example, the Tompkins/Tioga Neighborhood Legal Services office, advocacy and service groups directed at assisting victims of domestic violence, and judges in family court-both to assess the most pressing needs for additional legal assistance and to consult about the best ways to provide it using law students. I will develop the curriculum and materials for the course during the fall of 2011 , as well as expand my contacts with service providers in Ithaca to use as sources of client referrals when the course begins, which I plan for the spring of 2012 .

The development of such a course will benefit the local community. It will make a significant contribution to satisfying unmet legal need in Ithaca. I have personal experience of the depth of this need from my volunteer legal work at Loaves and Fishes and from conversations with persons at the local legal assistance office. The course will benefit the law school and university by adding substantially and appropriately to the clinical offerings currently

9. At this point, I was hoping to collaborate with a full-time clinical professor on this project rather than taking on all the supervision myself, but this hope did not come to fruition. As a result, there is an obvious need to cap the number who can enroll in the clinical portion each semester.

10. This tumed out to be inaccurate. Although I inquired of several law schools, I did not find another that had followed this model and could give me guidance. 
available at the law school and by raising the profile of Cornell as a provider of service to the community. It will introduce law students who are not in clinical courses to the real-world legal problems of groups in the community with which they may not be familiar and to the skills needed to help them. It will encourage students to continue public service work in the course of their subsequent careers because they will have met real people with real legal needs for which they cannot afford to pay and will have gained a sense of personal competency in serving those needs.

The grant application continued with information about my own qualifications to carry out such a project and required a supporting letter from my dean. Obtaining this letter allowed me to introduce him to the concept of a hybrid doctrinal-clinical course, which piqued his interest not only because of the new regulations requiring skills education credits during law school but also, at least in part, because developing such a service-related project would increase the profile of the law school both within the university and in the local community.

As it turned out, my proposal was not selected for funding by the university fellowship in service learning, but the dean responded positively to the idea that I spend my research leave developing the project nonetheless, instead of doing more standard academic research and writing. During this period, I would get to know the relevant groups and actors in the Ithaca legal community, assess what were the main unmet legal needs in this area of law, and develop the new course. So, the process of applying for the grant proved useful in working out my project, but ultimately unnecessary to creating the hybrid family law course.

\section{EXPloring UnMet Legal NeEdS in the Local Community}

Having the semester of leave during which to prepare the course was more important for me than it might be for other law professors because I was relatively new to Ithaca and New York law, having taught and practiced law in Illinois for decades. Since moving to New York State, I had done several pro bono cases in the local, lay-justice courts as well as appellate work, but I was unfamiliar with the trial court system and procedures. I needed to learn the local procedures before I could teach them to others.

I began by going to a colleague who taught legal writing and had practiced law in the area for a long time. ${ }^{11}$ She explained some unique features of local law-such as the right to an appointed attorney in all cases involving child custody and the provision of a separate Family Court for support issues, presided over by a magistrate and available without paying any filing fee. I posed the following question to her and to others I interviewed during that semester: What are the unmet legal needs in this county with respect to family

11. Interview with Andrea Mooney, Clinical Professor of Law, Cornell Law School, 219 Myron Taylor Hall, Ithaca (Aug. 30, 2011). 
law which law students would be capable of addressing (with instruction and supervision)? The answer to this question will obviously differ depending on the jurisdiction in which a law school is located and the social and economic context.

This colleague also provided me with the names of the key "players" in this field-judges in the various courts, court administrators with particular expertise and influence, local domestic violence resources and personnel, and attorneys serving indigent clients. She also suggested a number of possible unmet needs, especially ones created by recent cutbacks in funds for the court system. For example, a position for a clerk in the surrogate's court to help pro se litigants with adoptions had recently been eliminated. However, these cases tended to take a long time and would not be suitable for a semester-long course.

Next, I talked to the director of clinical programs at the law school and to a clinical faculty member who had been associated with the Legal Aid Clinic in the past. ${ }^{12}$ The Legal Aid Clinic, which had done family law along with other types of cases, was currently moribund. One clinical faculty member had retired, and the one who was still there restricted his instruction to social security cases and would be retiring within the year. He was an invaluable source of information about what the Legal Aid Clinic had done in the past, local procedures, and what types of cases might be appropriate for students. He also provided me with a copy of a manual that had been used in the past by students in the Legal Aid Clinic but was sorely out of date. For example, the divorce sections predated the availability of no-fault divorce in New York State. $^{13}$

A tentative answer to my question about the intersection of unmet legal needs and students' capacity began to emerge from my interviews with the Cornell clinical faculty I consulted. Everyone told me that divorces and initial support petitions were an area where help was needed. This conclusion was confirmed when I called the administrator responsible for appointment of counsel at the local court. She told me that the two issues about which she got multiple calls each day but had to turn down requests for appointed counsel were divorces and initial support petitions. ${ }^{14}$

The clinical faculty member with whom I consulted agreed on this priority. He stated that there would be many clients who had custody and support orders in place. It was not unusual to go first to Family Court, get assigned counsel for custody issues, and have the Department of Social

12. Interview with John Blume, Professor of Law, Director of Clinical, Advocacy and Skills Programs, Director of the Cornell Death Penalty Project, Cornell Law School, 306 Myron Taylor Hall, Ithaca, NY (Sept. 13, 2011); Interview with Barry Strom, Retired Clinical Professor of Law, Cornell Law School, G53 Myron Taylor Hall, Ithaca, NY (Sept. 19, 2011).

13. New York was the last of the states to allow no-fault divorce, beginning only in 2010. Sophia Hollander, Divorces Drag on Even After Reform, WALL ST. J. (May 6, 2012, 9:19PM),

http://online.wsj.com/news/articles/SB10001424052702304811304577368110112622548.

14. Telephone Conversation with Julia Hughes, Program Coordinator for Assigned Counsel, Supreme Court of Tompkins County (Aug. 31, 2011). 
Services take care of getting a support order in place, without charge for those who were recipients of public aid. If a client came in with a preexisting custody and support order, it could simply be continued in the divorce judgment granted by the Supreme Court but referred to Family Court for any further proceedings.

We discussed ethical problems that might arise in undertaking to represent these individuals. What if the client brought up some particular item of property he or she wanted, despite having divided property informally in a separation from his or her spouse? Was it ethical to tell them, "You can either give that up if you cannot get your spouse to agree to it, or I cannot represent you"? Moreover, if the client's spouse indicated that he or she would not contest the divorce but the couple needed an agreement drafted for them, what happened if the process of drafting it uncovered unresolved issues? In most cases involving clients with little or no property to divide, or couples who had been living apart for a long time (a not uncommon phenomenon in a state where no-fault divorce only became available in 2010), these problems would not arise, though. Problems are more frequent with respect to recent break-ups, where emotions are still intense and questions unresolved, especially in ones involving domestic violence. In most cases, this colleague advised, getting a support or custody order is more urgent than getting a divorce. So, students could assist a client with no support order in place to obtain one and advise the client to ask for appointed counsel and resolve custody issues first, and return to us to file for divorce later. He recommended that all students be processed for admission under the New York student practice rule at the beginning of each semester, so as to avoid all problems of whether something was or was not the unauthorized practice of law. ${ }^{15}$

Armed with this knowledge, I approached judges and service providers. A visit to The Advocacy Center in Ithaca, which is well staffed with non-lawyer personnel who are very knowledgeable about domestic violence and skilled at obtaining protective orders, convinced me that this was not an area that needed the students' help. A trip to Neighborhood Legal Services had the opposite effect. Despite some initial skepticism about the chaired professor from the elite law school coming down to use their client base for selfish purposes (simply to train students), the Legal Services lawyers welcomed me, especially after I told them of my background as a clinical teacher and convinced them that I was passionately committed to addressing unmet legal needs of poor persons in the area. At that time only one young lawyer, on a short-term and low-paid contract with Americorps, handled family law cases at Neighborhood Legal Services. She held a workshop a couple of times a year at which volunteers would assist unrepresented persons to fill out the forms they would need to obtain a divorce pro se. This lawyer was invaluable to me in the first semester of the new course, but further cuts in federal funding led to her

15. Most states have a court rule that allows third-year law students to practice under the supervision of a member of the bar. See, e.g., N.Y. COMP. CODEs R. \& REGS. tit. 22, $\S$ 805.5 (2013); Ill. S. Ct. R. 711 (eff. July 1, 2013). 
departure soon after, leaving only one paralegal at Legal Services and my students taking these cases for indigent clients. ${ }^{16}$

Next, I approached judges who played key roles in the adjudication of domestic relations cases. My first interview was with the Supreme Court judge in charge of the Integrated Domestic Violence Court, who also hears contested divorce cases. ${ }^{17} \mathrm{He}$ welcomed my project with great enthusiasm and offered to help. Although this may be unique to a small town like Ithaca, all the judicial personnel I consulted were extremely supportive and helpful. Some identified with the pedagogical goals and were eager to introduce law students on the hill to the nitty-gritty practice of law in the town. They also saw the potential for relieving the workload put on the courts by the provision of legal assistance to clients who might otherwise bring their cases pro se, which necessitates the investment of judicial resources to make sure the process is fair.

This judge suggested that filing support petitions on behalf of clients might be good experience for students because it involved some discovery, completing net worth statements, and an informal process in front of a magistrate with an immediate interim ruling, followed by a hearing. Alternatively, he suggested that representing clients alleging violations of support orders might be a good task because these petitions were given priority for hearing and would be ripe and straightforward, involving only a finding on willfulness and recommendation concerning a sanction, with all collections handled by the Support Collection Agency of the State Department of Social Services.

However, my next interviews-with the magistrate responsible for hearing support petitions and with the Family Court clerk-undermined some of the assumptions upon which this judge's recommendation rested. Although the first appearance on a violation petition took place within thirty days, followed by thirty days of fact-finding, it took two months or more, according to the support magistrate, before the first hearing on original petitions. ${ }^{18} \mathrm{My}$ subsequent interview with the Chief Clerk in Family Court revealed that even that estimate was optimistic. In fact, it was currently taking three months from filing to initial appearance on a new support petition, and five to six weeks from filing a violation petition to a hearing on it. ${ }^{19}$ This delay raised substantial problems for students enrolled in a semester-long course. If the course were cotaught with a clinical faculty member, these problems would not have been insuperable, because extended cases could be assigned to new students after the first student disappeared into our lengthy Winter break, summer employment,

16. By the third time I taught the course, the paralegal told me she would be leaving in a few months as well, leaving a dire situation for poor people seeking divorces in this county.

17. Interview with Hon. John C. Rowley, Supreme Court Justice, Supreme Court of Tompkins County (Oct. 5, 2011).

18. Interview with Alan D. Scheer, Family Court Support Magistrate, Tompkins County Courthouse, Ithaca, NY (Oct. 14, 2011).

19. Interview with Cheryl Lidell-Obenauer, Chief Clerk, Family Court, Tompkins County Courthouse, Ithaca, NY (Oct. 14, 2011 ). 
or graduation. I continue to believe that this is the ideal structure for the course, especially because many family law professors may not feel comfortable supervising the representation of live clients; indeed, some might not even be members of the bar. However, because there was no clinician familiar with domestic relations cases on the law school's clinic staff when I was setting up the new course, I had to work around this and other obstacles. Moreover, after having a student do some research on the possibility of limiting representation of a client to a certain defined stage of a case, I decided that I was unprepared to confront the ethical problems such an arrangement would present. When it came down to it, my name would be on the appearance, and I would be left with all the cases students did not finish.

On the other hand, after getting data from the clerks of both Family Court and Supreme Court about the numbers and types of petitions filed, I did not want to walk away from trying to find some way of helping to address this area of unmet legal need. ${ }^{20}$ The Supreme Court Clerk told me that 211 uncontested matrimonial petitions had been filed between January 1 and October of that year (2011), approximately 141 pro se, and 44 filed as a poor person. ${ }^{21} \mathrm{By}$ contrast, the Family Court Clerk reported a total of 135 new support petitions just between September 12 and October $10 .^{22}$ The support magistrate and the Family Court Clerk suggested that students might help out in some way without filing an appearance. Apparently there had previously been assistance with filling out support petitions prior to budget cutbacks. ${ }^{23}$ The clerk in that court responded favorably to the idea of law students coming in several hours a week to assist unrepresented persons with support petitions of all kinds-initial applications, modifications, and violations. ${ }^{24}$

The system we settled upon was as follows: the clerk would inform parties coming in to pick up a pro se packet for support that law students would be available to help them between one and four on Friday afternoons and invite them to sign up for such assistance. The clerk would keep the schedule and provide some private space where the students could work with their "clients" at or near the court office. My clinical colleague assured me that it would not be necessary to income-qualify the Family Court clients, because the student would simply be assisting someone who was proceeding pro se instead of representing them. ${ }^{25}$

20. Id.; Interview with Paula Nichols, Chief Clerk of Supreme Court, Tompkins County Courthouse, Ithaca, NY(Oct. 5, 2011).

21. Interview with Paula Nichols, supra note 21. Filing as a poor person denotes that the party had qualified as indigent and was thus permitted to file an action without payment of fees. N.Y. C.P.L.R $\$ 1101$ (McKinney 2011).

22. Interview with Cheryl Lidell-Obenauer, supra note 20.

23. Interview with Alan Scheer, supra note 19.

24. Interview with Cheryl Lidell-Obenauer, supra note 20.

25. The student practice rule requires that we not represent anyone who could otherwise get a lawyer, either by paying them or through court appointment of a local attorney. See N.Y. COMP. CODES R. \& REGS. tit. 22, § 805.5 (2013); see also 
In sum, I had now determined precisely which unmet legal needs law students would be able to perform competently within a semester. The main part of their casework would consist of divorce petitions in simple cases referred to us by the Legal Services office, which would have first checked that all the clients referred were income-qualified for free representation. ${ }^{26}$ This experience would be supplemented by spending Friday afternoons helping pro se litigants with support petitions.

Teaching the students-and myself-how to do all this was another matter, which $I$ describe in the section that follows.

\section{PReparing The COURSE}

I decided the way to familiarize myself with New York rules and procedures while preparing materials for the course was to draft a Training Manual for the students. I was particularly fortunate to have the previous Legal Aid Clinic manual from which to start, and two of its authors were willing to review drafts for me, even though one had been retired for some time. I excerpted the portions of the manual relevant to family law cases. They consisted of several parts, one of which was a multi-part discussion of New York law on divorce jurisdiction, grounds, property distribution, custody, support, courts and procedures, such as might appear in a casebook on family law. Another section contained models of all the forms that were necessary to file, along with checklists, websites to use, information about the student practice rule, a template for the initial client interview, and the like. The manual had not been used or updated for years. Updating the section on the law was the easiest part, much like what I have done as a doctrinal professor and casebook author for years. The forms were another matter.

I began by obtaining the thick pro se divorce packet from the court. Obtaining an uncontested divorce in New York State requires filing about fifteen forms (and maybe more if children are involved) and at least three more to obtain a support order. It took me several days to make my way through all of these forms with some understanding, causing me to wonder precisely how a pro se petitioner would fare. After getting the official forms, I compared them with ones I obtained as samples from Neighborhood Legal Services and from an Albany-area women's bar association project, as well as with the previous forms used by the Legal Aid Clinic, which were outdated. I decided the best way to structure the revised manual would be to intersperse the forms into the discussion of substantive law, so that students would understand the legal basis for each form and its function.

Application of Cornell Legal Aid Clinic, 273 N.Y.S.2d 444, 445-46 (N.Y. App. Div. 1966).

26. The income standard derived from $125 \%$ of the official poverty threshold defined by the Department of Health and Human Services in 2011 was $\$ 13,613$ for a single person and $\$ 27,938$ for a family of four. These guidelines are adjusted annually when new HHS statistics become available; source of update at that time was 76 Fed. Reg. 3637 (1/20/11). 
I had some reservations about using forms at all, because one pedagogical objective of the course was to teach students to draft court documents by themselves. Then, however, I remembered my own first days in private practice, when I borrowed samples of previous complaints, interrogatories, and other documents from colleagues in the firm where I worked in order to learn how to draft my own. So, I decided to provide similar models for my students. After a good deal of work, I had drafted models for each form that needed to be filed in a simple divorce, combining and updating the best features of the ones I had obtained and including choices on each form to tailor it to the facts of a particular case. ${ }^{27}$ The Training Manual consisted of about 125 pages, and I have added to and revised it every subsequent semester-not because New York State keeps changing its law, but because I become more familiar with the subtleties of its procedures. I then pass on what we learn through trial and error in one semester to students in the next.

It was clear I would not be able to accept into the supplemental clinical section all of the fifty to sixty students who typically register for the family law course on an annual basis. I simply could not supervise that many students alone. I made an attempt to recruit additional supervising attorneys by appealing to the local women's bar association, offering hour-for-hour CLE credit in payment for their time. Two lawyers with domestic relations experience responded. I was grateful for their help, but they both had busy practices, so I could not assign more than one student to each. I calculated that I could supervise seven or eight students and their cases myself, so I decided to admit a total of nine students into the clinic. Those who were interested were required either to have previously taken family law or be co-registered in it and to submit their curriculum vitae and a letter of application explaining their interest in the clinical component. More students than I could accept applied, but I was able to prioritize them according to their past legal work and interests, the apparent genuineness of their interest in taking the clinical component of the course, their year in law school (seniority prevailed), and whether they had had the opportunity to do clinical work in law school before. I soon had my nine students and was ready to begin. I sent out the new manual to the students enrolled and asked them to read the first section (on the law and procedure for getting a divorce in New York State) by the first class.

\section{THE FIRST SEMESTER, AN EXPERIMENT}

The clinical section of family law was scheduled to meet for two hours once a week in the late afternoon. The first two class meetings focused on teaching the students the law of divorce in New York State. Still unsure of myself, I asked one of the local practitioners who was supervising a student to sit in on those sessions to correct any inaccuracy or supplement my presentation as necessary. In the first class session, we made our way through the law and documents with which it was necessary to be familiar from the

27. Any reader who would like to see the Training Manual I produced may contact me at cgb28@cornell.edu. 
initial client interview through filing the petition for divorce (referred to as "Round 1"), with me leading them through the materials in the Training Manual as we went along. In addition, I distributed to them the client folders I had obtained from Neighborhood Legal Services, along with forms I had drafted to obtain consent to representation by law students and a more general consent form that explained the duties and obligations of both the client and legal representative, including the client's obligation to cooperate in a timely fashion. $^{28}$

We also discussed some general information about the clients the students would be interviewing. Key information that took the students by surprise was that their clients were unlikely to have continuous access to email communication and might not even have a telephone. (In fact, the most frequent problem was that clients ran out of pre-purchased minutes before the end of the month, so the easiest time to reach them was just on the first day of each month). I reminded students of the availability of the United States mail as a method of communication and sent them a simple template with a Cornell Legal Aid letterhead to use as stationery. Yet, by the second week's class, only a handful of students had in fact reached their clients to make an appointment for the initial interview.

The second class focused on obtaining support orders, modifying them, and remedies for violation-that is, the information the students would need to begin their sessions as legal advisors in Family Court later that week. Students signed up in teams of two to cover all the Friday afternoons through the rest of the semester. Again, the experienced local practitioner attended the class session on support orders, lest I misinform the students about something or leave out some informal, but critical, twist of local procedure.

The third week's class was a kind of case rounds, during which students reported on their progress, explaining any problems they were encountering, with the group and myself offering advice. This dialogue was somewhat difficult to carry out while attempting to protect client confidentiality. I suspect the solution might be to have all the members of the class sign a joint representation and confidentiality agreement, but I have continued to struggle with this ethical issue.

Only one or two students were close to filing their initial round of documents at that point, three weeks into a thirteen week semester, so I cancelled the following week's group class and asked all the students to get their Round 1 first drafts to me and schedule an individual appointment in place of class the following week. I did this at various points during the semester. It also gave me some flexibility when I needed to attend a conference or had some other conflicting obligation. Because every document had to go through multiple drafts and all had to receive my approval, and in many cases my signature, prior to filing, this did not add overly much to my workload.

28. This form allowed us to "fire" one client who repeatedly failed to respond to the assigned student's attempts to meet with him. 
The remaining class sessions were divided between instructional sessions, sessions for questions and common problems, and presentations by visitors. After a month of the semester had gone by and one student had actually filed all the Round 1 documents, I held a session about "Round 2"-that is, all the documents necessary to prepare and file to obtain a judgment once the period after service of process had expired. Service of process was a frequent question raised at "case rounds" sessions. In cases where the defendant was clearly cooperative and it was safe to do so, students served the complaint themselves, arranging to meet the defendant either at the law school or in some public space with a notary public available to do so. In other cases, we hired a private process server because the sheriff would take too long to serve the papers if we wanted to complete the divorces within one semester (I was assigned a small budget within the legal clinic to pay for this).

There were two outside speakers. I invited a lawyer prominent in the local collaborative law movement, who was also supervising one of the students, to speak to the class on that topic. Also, one of the judges I had gotten to know came in to talk about the Integrated Domestic Violence Court and the problems faced by sitting judges. Both sessions were very well received by students.

The course as a whole was also well received, although at our final evaluation session several students argued that it required too much work for just one credit. However, only about half of the cases were completed by the end of the semester. Sometimes this resulted from a student having dropped the ball, but more often it did not. In one case, for example, after valiant efforts to locate the defendant, the student had to give up and undertake the lengthy process of obtaining permission from the court to serve notice by publication in a local newspaper, find out how to do so, and wait until the series of weekly publications of the legal notice had taken place. The bottom line, however, was that I was left with a substantial number of cases to complete when summer arrived, even after insisting that students submit drafts of all the documents that would be required. Fortunately, I was able to hire a law student to work on completing these cases over the summer, but this was not ideal. I wanted each clinical student to develop a relationship with his or her client and accompany that client all the way through the process.

\section{IMPROVING AND INSTITUTIONALIZING THE NEW COURSE}

I repeated the family law course and clinic the following semester, but this time around I knew I would be leaving on sabbatical at the beginning of January and thus not available to finish cases students did not complete. I was, therefore, much stricter about monitoring students' progress on their cases, telling them upfront that $I$ expected them each to obtain a final judgment for their divorce client by the end of the semester. I gave target deadlines for filing each of the rounds of documents and asked for weekly status reports on their progress. I compiled these reports into a large document that described each student's progress, my instructions to them, and their responses on a week by week basis, noting the dates on which key markers of progress (filing, service, etc.) had been achieved. This document was immensely helpful to me in assigning grades at the end of the semester. For example, if I was required 
repeatedly to return drafts for revision until a student got it right (a few were surprisingly sloppy in the work they submitted to me), that information was available both to explain any delays and to assess the diligence of their work. Being so familiar with the students and the work each had been doing made the assignment of grades relatively easy. Although the cases assigned to them raised different levels of complexity and difficulty, and some delays and difficulties were caused by clients, I treated this as the luck of the draw because all these things were impossible to predict in advance. That is, I neither penalized students for difficulties caused by clients nor rewarded them for dealing with a legally more difficult case. Their grade was based on how well they had handled the case to which they had been assigned.

I changed a number of things about the course based on the first semester's experience. In response to students' arguments about the workload, I added a second credit for the clinical component. I also spent a week during January revising the Training Manual, with the intent to clarify various points I had been required to correct repeatedly in student drafts. I also added a few documents and information that had turned out to be helpful during the first semester.

Teaching students by giving them model documents continues to present problems. Some students slavishly follow the model without any consideration of its appropriateness to the facts of their case. Yet, I don't see any alternative to giving them a model and telling them to adapt it to their cases; some "get" it and some don't. Hopefully they all have learned after I have sent drafts back for repeated revision, a task made immensely easier by the computer's 'track changes" and commenting functions. One student later commented upon the draft-revision process as particularly important to her: "I really liked the fact that you took time to revise our documents because I was able to learn, from you, how to draft clean and concise legal documents." My goal remains that they should know what they are doing when they draft each part of each document and why they are doing it.

I also began to accept slightly more complicated cases during the second semester, ones involving the necessity of negotiating and drafting lengthy agreements, serving out-of-state defendants, registering out-of-state orders for custody and support, and the like. As a result, I spent less time in group sessions and more on individual tutelage. I am not sure if this change was entirely for the good because it deprived students of the ability to learn from one another's cases.

Using an idea borrowed from a clinical teacher who gave a talk at the law school that semester, ${ }^{29}$ I also instituted a final session during which each student was required to propose a change in the law, procedure, or local practice of family law based on his or her experience during the semester and to argue for that change. This made an extremely interesting class, one that also required students to practice their advocacy skills. Among other things,

29. Credit for this idea must be given to Professor Beth Lyon, Director of the Farmworker Legal Aid Clinic at Villanova University School of Law. 
students suggested that New York should require the filing of a Parenting Plan in every case involving joint custody (a legal gap that caused significant problems in the case to which that student was assigned), that the law should take into account the needs of children living in a family who were not children of the marriage (a common phenomenon), that modification of child support awards be made easier, and that retroactive modification be allowed. Although I did not agree with every suggestion, each one had emerged from difficulties and injustices students had encountered in pursuing cases on behalf of their clients, thus linking theory and practice. One creative student came up with a tech-savvy solution for parties divorcing pro se: installation of computer kiosks in the courts that would be programmed to ask the individual a series of questions in a user-friendly fashion and then fill out the necessary forms for them to file, rather like the computer programs many of us now use to file our income tax returns. ${ }^{30}$

Over the course of the year I taught Family Law with a clinical component in two successive semesters, I also began to consider myself part of the clinical faculty at the law school and attended their regular meetings. This has allowed me to continue to press for the addition of a clinical faculty member who would do family law cases, who could teach the clinical component of Family Law after I am no longer available to do so, and who would be available to take on cases that turned out to be more complex than the two-credit semester students could complete. It often happens that a case that appears simple at the outset turns out to be much more difficult as it progresses. As a prior clinical faculty member wrote in the old manual, "There are no simple divorces."

Moreover, the next time I teach this hybrid course, my students will be included in a new all-clinic program of several classes on client interviewing and other relevant skills that will be taught by the clinical faculty as a whole, myself included. In other words, I have been working to institutionalize the new hybrid course at Cornell Law School.

\section{Student Response to THE NEW COURSE AND MY RESPONSE TO IT}

In this section, I describe the responses to the family law clinic by the first two semesters of students who helped me learn how to teach it.

An additional change I made during the second semester of teaching this course was to assign a short (two- to three-page) reflective paper describing each student's experience of the clinic, to be presented to the class at the end of the semester. This paper and presentation served several functions. It gave the students an all-important opportunity to reflect on what they had learned, how it had affected them and perhaps changed their perspectives on a variety of issues. It gave me an opportunity for valuable feedback, not just in the form of student evaluations typically received after the semester was over. Thus we were able cooperatively to discuss ways in which the course might be made

30. By the fall of 2013, something like this had, in fact, been set up in the Family Court for filling out support petitions. 
better the next time it was taught. This assignment also revealed problems 1 would not have known existed because they took place during the students' sessions in Family Court.

I was surprised, for example, to find that the students found the work difficult: The paperwork is incredibly difficult and time consuming. I don't know how some individuals could do it pro se. Even with my legal knowledge thus far, I still found myself confused by the documents and aggravated about how repetitious many of the documents were. ${ }^{31}$

In other words, what had come to seem simple to me was challenging to the students - a good result overall because it signified that they were required to stretch their minds to learn new things while I had become somewhat expert at the process over the two semesters. One student found himself struggling with long-term problems with organization but concluded that, "Over the course of a semester I developed a system that though far from perfect, eliminated the need to spend a lot of time comparing drafts to determine which one I wanted. I am slightly more organized as a result of my experience in the clinic."

Students continued to be troubled by problems communicating with their clients, complaining that they were hard to reach by telephone, cancelled meetings, and did not return phone calls for long periods. Some began to realize that part of the problem was that they, as law students, were also not always available:

I also realized how important it was to be accommodating to your client. It encouraged my efforts to be available on her time, and make sure I had my phone on me at all times, because calls were few and far between, and needed to be taken advantage of when they had happened.

While limited cell phone minutes presented one kind of problem, other clients had minimum-wage jobs with long hours and employers who did not tolerate telephone calls while on the job. This conflicted with the law students' ability and determination to get work done on their own timetable. One student who was particularly frustrated thought she should have set up a regular schedule of weekly phone calls with the client and suggested that assigning students in teams would help with the clients' ability to reach one or the other of them, and vice versa.

The students were quite clearly being exposed to people whose lives were quite different from their own. One commented:

The clinic exposed me to a population I am not often exposed to in everyday life. It made me aware of difficulties that had not previously occurred to me (such as only having a phone for part of the month). My client's membership in a nontraditional family where none of the children had the same

31. All of these unattributed quotes are from students in the Fall 2012 section, who were told at the time of the assignment that I planned to use excerpts from their reflective papers in this article but would keep their comments anonymous. 
father exposed me to some of the ways current law does not fit the lives of many Americans. ${ }^{32}$

Proceeding with such different assumptions about life made initial client interviews difficult for some students, especially with respect to the parentage of the various children within the household. One student professed being frustrated at attempting to get information from clients that the student assumed would be at the tip of their tongues, such as birthdays and wedding dates. I surmise that the students' interviewing skills, and especially their ability to communicate across differences of gender, class, and culture, were rough at first. I did not myself sit in on client interviews except on one occasion during the first semester of the course, when the client clearly needed some straight talk from an attorney capable of giving legal advice. ${ }^{33}$ From the student's reaction after the session was over, I realized that my own style of interviewing, developed over decades, was obviously quite different from the stage the student had reached. Attendance at the all-clinic class on client interviewing should help in the future to some extent, although each lawyer needs to develop his or her own style over the course of years of practice.

Most of the students commented on how participation in the clinic had introduced them, in a way that other classes did not, to the human element in the law, in both its good and bad aspects. One commented, for example, that:

With both these clients I had ideas of efficiency in my head where I was sure I could have them divorced in a matter of weeks. However, I had forgotten about the human element that comes with practicing family law. It can be difficult for individuals to put aside their personal feelings.... Even if students are taking the family law course, I believe that understanding the "human element" of working in the field is incredibly important.

Others were immensely grateful for the personal connections they formed with their clients and the ability to help them with an important life transition. As a result, one student decided that she would like to pursue a career in family law:

I was able to see a side of legal work that clicked with me. It was interesting to me to see the legal side of this couple's divorce, while also being a part of a new stage in the life of my client. Her marriage was ending and her life was changing forever. The last time I saw her, she thanked me for all the work I had done and told me that she felt so thankful that $I$ had been assigned to work her case. She felt

32. This student had taken my Family Law course the previous semester, in which I spent a great deal of time on non-traditional families. But, this insight seems to have only really penetrated when he met real people in these situations.

33. The client's conduct was endangering her relationship to her children. She needed to be presented starkly, but sensitively, with the choices before her. 
that I was destined to be a part of her life transition and that she was destined to be my first legal client. Working in the clinic allowed me to see the human side of the legal profession.

At times, the human and emotional side of legal representation in this field was a bit overwhelming for the students. They described being terrified when they first went to support court and were glad that they were assigned to go in teams so that they could work together to figure out how to handle things with which they were unfamiliar. Gradually, as they made repeat visits to support court, their confidence grew. Yet, they reported, "many of our support court clients were upset and it was our job primarily to listen to their stories," a task for which many law students are not well prepared. At the final class session, a story emerged of a time when two students were confronted with an exceptionally distraught client at Family Court and did not know what to do. Fortunately, one of the two had a history in psychology and preschool teaching, which she found useful:

As a teacher, I was often in sticky situations, whether I was listening to a distraught parent suffering from domestic violence or calling child protective services. I really learned how to listen to clients and figure out what their needs are and I believe this allowed me to be successful at support court.

It is tempting to look only for psych majors, preschool teachers, and students with previous careers in social work (of which $I$ had one) when choosing whom to admit to the clinic, but this is obviously impossible and would not be fair if it were. These are skills all lawyers need to learn. Just as they need to come to terms with and accept their clients' foibles and weaknesses, they also need to learn to interview skillfully and sensitively and to deal with their own emotional reactions in the process. Training by simulation can be helpful, though. At the clinic meeting to plan the all-clinic classes on client interviewing, I requested that we use one scenario in which the client gets emotionally upset, so that we could discuss with the students various ways of handling the situation. This may help future students to be a bit more prepared when something like that occurs, or at least not totally surprised.

Finally, students participating in the clinical component of Family Law were impressed by the contribution their labors were making to address unmet legal needs in the local community, unmet legal needs of which they had previously been unaware. One said that, in six years of residence as a student in Ithaca, he "never really felt part of the Ithacan community until this semester." Another reflected at more length on this aspect of the course:

Most of all, this clinic showed me how important it is to have this form of legal aid for people who cannot afford a lawyer to appear for them and handle their divorce. The fact that we are almost the only ones providing this aid in the Ithaca area is disheartening. In the case of my client, she desperately wants to be separated from her husband. They have domestic relations issues in the past, and she is fearful of 
him making claims to her property and holding her liable for his misdeeds and debts. Most likely my client is not the only one who is in this situation. She truly wants to get this divorce, and without us, I do not know how she would have accomplished it, which made the clinic feel like a really important contribution to Tompkins County.

This was extremely gratifying to hear, given that it had been such an important part of my motivation for creating the course in the first place. Almost as gratifying as the comment from another student, the one all professors love to hear, to the effect that "My clinic experience is, so far, my favorite part of law school ...."

\section{The Future of the Clinical Component of Family LaW}

The following semester, I was to be on sabbatical, so neither the family law course nor clinic were offered. When I returned, therefore, there was no backlog of students who had taken family law, and that course was not offered in the first semester. I, therefore, offered the clinic without requiring coregistration, as an experiment. When I asked the previous semester's students what they thought of that idea, they replied that the co-registration system was ideal because they needed the substantive law to understand and contextualize the skills. One commented that:

While we do spend a good amount of clinic class time at the beginning of the semester reviewing all of the divorce forms, the nature of the course prevents us from discussing how these forms fit into broader issues of divorce, custody, and support. ... Second, the ultimate goal of education seems to require that a clinic student also take the substantive course, since an importance purpose of the clinic program is to allow us to put our education into practice. Few of us will ultimately become family law practitioners, but we will still have gained the ability to translate our doctrinal knowledge into a functional aptitude.

While I understand and sympathize with the issues this student was raising, I wonder whether I can address some of them by spending more time in the initial classes on a summary of divorce law doctrine and thereby remedy the problems he described, at least in part. After all, even the students who were co-registered had not covered most of the topics pertinent to their cases by the time they filed their petitions in court. At any rate, I think this is worth trying, in order to make sure that these free legal services are available on a continuous basis.

Another change I am considering, suggested by several students, is assigning students to cases in teams of two. One of last semester's participants made a particularly cogent argument for this approach:

Since a great deal of our time, especially initially, is spent groping our way through the applicable statutes and forms, I think it could be 
very beneficial to have a partner on each case with whom to discuss problems and formulate strategies. We are currently limited in our ability to do so by the attorney-client confidentiality about which we were warned at the beginning of the semester. A partner system would also ensure that no question or issue is overlooked when meeting with the clients, and it provides a simple solution to the concerns [about safety] about serving process alone. Having two students on each case would give our clients more flexibility because they would not be limited by one student's schedule.

Problems of shirking and free-riding, he suggested, could be addressed by assigning two cases to each team of two and making each student the primary representative on one of the cases and the secondary representative on the other. Given the amount of support among the students for this approach, I will almost certainly try it the next time I teach the course. Developing teamwork skills is also valuable for lawyers.

\section{CONCLUSION}

In conclusion, I am very satisfied thus far with the results of my experiment with a hybrid family law course and clinic. Response from the students has been enthusiastic, and they clearly have gained skills important to the practice of law. Judges, court personnel, and practitioners in the local community have also responded well to my experiment. Perhaps most important, my students have now helped at least fifteen indigent clients in this community, meeting a substantial legal need. With further cutbacks in free legal services, this has become increasingly important.

I offer my experience as a model for adoption at other law schools and in other communities, although it will need to be adapted in each instance to local laws, procedures, and needs. I would also urge teachers of other substantive law topics to initiate similar experiments. Clinics attached to courses in real estate transactions, income tax, and trusts and estates are clear candidates. What better way to learn tax law than by helping someone fill out his or her tax return? Moreover, supervising a small number of students (a maximum of seven or eight) in these tasks is fun-allowing the professor to develop a close and cooperative relationship with her students and to remember some of the reasons we all became lawyers in the first place. 